\author{
Maria Bialasiewicz* \\ Uniwersytet Szczeciński
}

\title{
KREATYWNOŚĆ I TALENT W KONCEPCJI KAPITAKU LUDZKIEGO
}

\section{Streszczenie}

Problematyka artykułu dotyczy koncepcji kapitału ludzkiego w warunkach organizacji ewoluujących ku organizacji kreatywnej. Trend ten wywołuje zmiany przede wszystkim w sferze zarządzania kapitałem ludzkim zorientowane na pozyskiwanie, utrzymanie i rozwój pracowników o wysokim potencjale. To ci pracownicy dysponują szczególnie wysokim potencjałem twórczym, a więc m.in. zdolnościami kreatywnego rozwiązywania problemów. W artykule podjęto podstawowe kwestie w ciągu rozważań: kapitał ludzki - kreatywność jako kompetencja - talenty. Wskazano też tzw. dobre praktyki z tej dziedziny.

Słowa kluczowe: kapitał ludzki, kreatywność, talenty

\section{Wprowadzenie}

Pod wpływem wielu zjawisk, takich jak np. przewartościowanie źródeł kreowania wartości firmy z kapitału finansowego i rzeczowego na rzecz kapitału ludzkiego, przekształcenia struktur hierarchicznych w struktury heterarchiczne, wzrost znaczenia zasobów niematerialnych i ,miękkich” narzędzi zarządzania, wzrost znaczenia elastyczności funkcjonalnej i ustawicznego rozwoju, następuje nie tylko transforma-

\footnotetext{
*Adres e-mail: maria.bialasiewicz@wneiz.pl.
} 
cja organizacji tradycyjnej w organizację wiedzy, czy uczącą się, co w organizację kreatywną. Kluczowe staje się więc wykorzystanie różnych sposobów tworzenia i stymulowania kreatywności w organizacji. Aby organizacja mogła być uważana za kreatywną, to konstrukt ten powinien funkcjonować na każdym poziomie - organizacji jako całości, zespołów i jednostek.

Celem artykułu jest identyfikacja kluczowych aspektów zarządzania kapitałem ludzkim w organizacji w kontekście kreatywności i jednego z jej źródeł, tj. pracowników o wysokim potencjale.

Niniejsze opracowanie przygotowano na podstawie studiów literaturowych, głównie z zakresu zarządzania kapitałem ludzkim, a także źródeł internetowych oraz opracowania PARP będącego swojego rodzaju raportem nt. wzrostu innowacyjności na bazie kreatywności.

\section{Kreatywność jako składnik kapitału ludzkiego}

Pojęcie kreatywności wywodzi się od łacińskiego creatus, czyli twórczy, i powszechnie oznacza zdolność do tworzenia czegoś nowego, oryginalnego, dotychczas niewystępującego, a więc prowadzącego do innowacji, przekładającego się na wynalazki, produkty/usługi, procesy i metody. Bez kreatywności nie ma innowacyjności. Kreatywność jest też określana jako zestaw cech danej osoby pozwalający na ciągłe poszukiwanie nowych rozwiązań. W każdej organizacji źródłem kreatywności są jej pracownicy. Pojęcie kreatywności wiąże się nierozerwalnie z innowacjami i kapitałem ludzkim ${ }^{1}$.

Pojęcie kreatywności jest terminem wieloznacznym. W niniejszym opracowaniu jest rozważane w odniesieniu do kapitału ludzkiego, a zwłaszcza ludzi o wysokim potencjale. Główną przesłanką uzasadniającą taki kierunek rozważań jest sygnalizowany wcześniej fakt znajdujący odzwierciedlenie w następującej opinii: „Kapitał ludzki stanowi główne źródło wartości oraz czynnik determinujący pozycję konkurencyjną i jest jedynym rodzajem kapitału, który może dodawać do siebie i przez siebie" ". Także w aspekcie strukturalnym powszechnie wskazuje się na kreatywność

1 Innowacyjność organizacji w strategii inteligentnego i zrównoważonego rozwoju, red. J. Wiśniewska, K. Janasz, Difin, Warszawa 2012, s. 41, 50.

2 J. Fitz-enz, The ROI of Human Capital, AMACOM, New York 2000, s. XII, za: Elastyczne zarzadzanie kapitatem ludzkim w organizacji wiedzy, red. M. Juchnowicz, Difin, Warszawa 2007, s. 18; 
jako składnik kapitału ludzkiego zarówno w wymiarze jednostkowym, jak i organizacyjnym, a zwłaszcza w podejściu kompetencyjnym do zarządzania tym kapitałem. I tak np. L.J. Roosa, G. Roosa i N.C. Dragonetti definiują kapitał ludzki jako kompetencje, postawy i sprawność umysłową, a tę ostatnią jako umiejętność analizowania i syntetyzowania, wyciągania wniosków, dostosowania się do nowych warunków oraz skłonność do innowacji ${ }^{3}$. S. Domański pisze, że kapitał ludzki to zasób wiedzy, umiejętności, zdrowia i energii witalnej zawartej w człowieku i w społeczeństwie jako całości, określający zdolności do pracy, adaptacji do zmian w otoczeniu oraz możliwości kreacji nowych rozwiązań ${ }^{4}$.

Kategoria kapitału ludzkiego jest pojęciem wieloznacznym i nie ma ogólnie przyjętej do tej pory definicji, co wynika z wielu powodów, np. szczebla prowadzonych rozważań w skali makro, organizacji, osoby, przyjętych przez badaczy założeń czy ułomności przeniesienia literatury zagranicznej na rynek polski. Ponieważ pojęcie kapitału ludzkiego jako takiego nie stanowi głównej domeny niniejszych rozważań, dlatego pominięto kwestie związane z różnymi koncepcjami tego kapitału, a trzeba tylko dodać, że stanowił on już przedmiot zainteresowań klasyków ekonomii. Znaczący wkład w rozwój teorii kapitału ludzkiego wnieśli m.in. tacy ekonomiści, jak W. Petty, A. Smith, A. Muller, G.S Becker, T.W. Schulz, czy na gruncie polskim J. Strużyna, S. Domański i wielu innych ${ }^{5}$.

Zarzadzanie kapitatem ludzkim. Procesy - narzędzia - aplikacje, red. M. Juchnowicz, PWE, Warszawa 2014, s. 33.

3 J. Roos, G. Roos, N.C. Dragonetti, Intelectual Capital - Navigating in the Business Landscape, Macmillan Press, London 1997, s. 36, za: Zarzadzanie kapitałem ludzkim..., s. 34.

4 S.R. Domański, Kapitat ludzki i wzrost gospodarczy, Spis, Warszawa 1993, s. 20; idem, Kapitat ludzki. Stan i perspektywy, w: Kapitał ludzki, RSSG przy Radzie Ministrów, Warszawa 1998, za: Zarządzanie zasobami ludzkimi. Tworzenie kapitału ludzkiego w organizacji, red. H. Król, A Ludwiczyński, Wydawnictwo Naukowe PWN, Warszawa 2006, s. 111.

5 Szerzej na temat kapitału ludzkiego i ewolucji poglądów w tym zakresie m.in. w: Elastyczne zarządzanie..., s. 34 i n.; Zarzadzanie zasobami..., s. 110 i n.; A. Pocztowski, Kapitat intelektualny a zarzadzanie zasobami ludzkimi, Zeszyty Naukowe Akademii Ekonomicznej w Krakowie 2005, nr 629, s. 14; J. Strużyna, Wymiary kapitału ludzkiego, w: Ksztattowanie kapitału ludzkiego firmy, red. B. Kożuch, Wydawnictwo Uniwersytetu w Białymstoku, Białystok 2000, s. 48, 52-53; S.R. Domański, Kapitat ludzki i wzrost..., s. 67; J. Strużyna, Kapitat ludzki i przedsiębiorczość - aspekty teoretyczne, w: Kapitat ludzki a kształtowanie przedsiębiorczości, red. M. Juchnowicz, Poltext, Warszawa 2004, s. 26-27; Z. Janowska, Zarzadzanie zasobami ludzkimi, PWE, Warszawa 2010, s. 11-34; Podstawy zarzadzania przedsiębiorstwami w gospodarce opartej na wiedzy, red. B. Mikuła, A. Pietruszka-Ortyl, A. Potocki, Difin, Warszawa 2007, s. 73-83; Z. Antczak, Kapitat intelektualny i kapitat ludzki w ewoluujacej przestrzeni organizacyjnej, Wydawnictwo Uniwersytetu Ekonomicznego we Wrocławiu, Wroclaw 2013; T.W. Schulz, Investing in People: The Economics of Popultion Quality, University of Ca- 
Warto jednak zwrócić uwagę na „naturę” kapitału ludzkiego. Szczególną jego cechą jest możliwość samoistnego wzrostu wartości tego kapitału dzięki ustawicznemu uczeniu się, czy nabywaniu doświadczenia i dlatego rozwój pracowników stanowi strategiczny cel każdej nowoczesnej organizacji. Cechą tego kapitału jest też to, że jest wynajmowany pracodawcy na podstawie określonych stosunków prawnych, a więc może on nim zarządzać, a każde odejście pracownika zmniejsza kapitał ludzki o jego wartość. Wartością będzie tylko tyle, ile wiedzy pozostaje w organizacji po wyjściu pracowników do domu. Wiedza, która została sklasyfikowana, stanowi wiedzę organizacji i przyjmuje postać kapitału intelektualnego. Dlatego zadaniem zarządzających jest utrzymanie pracowników o wysokim potencjale, gdyż ich odejście stanowi utratę talentu, know-how czy nabytej wiedzy ${ }^{6}$.

Powracając do głównego wątku rozważań, tj. kreatywności jako kluczowego elementu kapitału ludzkiego, należy rozpocząć od definicji kreatywności. Użycie słowa „kluczowy” wynika z powszechnie akceptowanego stwierdzenia, że „kolejną formą po organizacji uczącej się będzie organizacja kreatywna"7.

Pojęcie kreatywności jest terminem wieloznacznym i często jest traktowane jako synonim pojęcia twórczości. Jest przedmiotem zainteresowania wielu dyscyplin naukowych, jak np. socjologii, psychologii, filozofii, ekonomii czy nauk o zarządzaniu. Według słownika wyrazów obcych „kreatywny” to „tworzący coś nowego lub oryginalnego, twórczy"». Taki sposób rozumienia kreatywności jest zbieżny ze słownikową definicją twórczości obecną w języku polskim i angielskim (creativity) oznaczającą ,proces psychiczny, którego efektem jest powstawanie nowych rozwiązań, idei, koncepcji, produktów czy też wytworów artystycznych, uznawanych za nowe i użyteczne"9. Inna definicja określa twórczość jako umiejętność wytwarzania czegoś, myślenia, wyrażania siebie, pewne spojrzenie na świat w sposób indywi-

lifornia, Berkley 1981, s. 21; Kształtowanie kapitału ludzkiego w organizacji, red. M. Białasiewicz, Wydawnictwo Naukowe Uniwersytetu Szczecińskiego, Szczecin 2013, s. 21 i n.

6 Zarzadzanie kapitałem..., s. 34; A. Sajkiewicz, Człowiek-kreator wartości przedsiębiorstwa, w: Zarządzanie wartościa firmy, red. A. Szablewski, Poltext, Warszawa 1999, s. 79.

7 M. Brzeziński, Organizacja kreatywna, Wydawnictwo Naukowe PWN, Warszawa 2009, s. 10 .

8 Stownik wyrazów obcych, Wydawnictwo Naukowe PWN, Warszawa 2004, s. 521.

9 Zarzadzanie kapitatem..., s. 83. 
dualny, kreatywny, inteligencja, aktywność, odwaga przedstawiania swego zdania, otwartość na świat ${ }^{10}$.

Czy pojęcia „kreatywność” i „twórczość” są tożsame? W wielu przypadkach są tak traktowane, ale wydaje się, że o ile cecha kreatywności przynależy ludziom i organizacjom, które tworzą, i związana jest z pewną zapowiedzią, obietnicą stworzenia czegoś nowego, oryginalnego, to cecha twórczości przynależy zarówno osobie, jak i przedmiotowi i zwykle wiąże się z jakimś wytworem ${ }^{11}$. W literaturze przedmiotu wyróżnia się cztery poziomy twórczości: płynna, skrystalizowana, dojrzała, wybitna, a kreatywność odnosi się do dwóch pierwszych wymienionych wymiarów, przy czym za podstawowy poziom kreatywności uznawany jest poziom pierwszy, odwołujący się do cechy wrodzonego, egalitarnego charakteru twórczości ${ }^{12}$.

Kreatywność może być traktowana jako jedna z cech postawy przedsiębiorczej i rozumiana jest jako potencjalna zdolność człowieka do wykorzystania rzeczy twórczych lub myślenia i działania twórczego, ale bez produktu działalności twórczej, bo ten pojawia się jako rezultat procesu innowacyjnego. W tym ujęciu pojęcie kreatywności jest zbieżne z pojęciem postawy twórczej, akcentującej związek aktywności twórczej z cechami osobowości determinującymi specyficzny sposób funkcjonowania i reagowania na rzeczywistość ${ }^{13}$. P.F. Drucker, definiując przedsiębiorczość, akcentuje zawarty w niej pierwiastek twórczości i nowatorstwa i wykazuje, że jest cechą danej osoby czy instytucji ${ }^{14}$.

Na gruncie nauk o zarządzaniu kreatywność jest traktowana jako kompetencja osobista przez badaczy przyjmujących założenie, że jest ona wymiarem charakterystyki osobowościowej związanej z efektywnością działania. Podobnie ujmowane

10 http://psychologia-twórczości-wykłady.org/wykład/72_psychologia-twórczości-pojęcie-twórczości.html (4.02.3015).

11 http://www.kluczdokariery.pl/twoja-kariera/rozwój-osobisty/kreatywność/art.,2kreatywnoscw-pracy-,html (3.02.2015).

12 E. Nęcka, Wymiary twórczości, w: Nowe teorie twórczości. Nowe metody pomocy w tworzeniu, Oficyna Wydawnicza Impuls, Kraków 2002, s. 45-50; E. Jerzyk, Kreatywność - uwarunkowania i ocena, w: Kreatywność w biznesie, red. E. Jerzyk, G. Leszczyński, H. Mruk, Wydawnictwo Akademii Ekonomicznej w Poznaniu, Poznań 2006, s. 67-72; Innowacyjność organizacji..., s. 3-4.

13 Zarzadzanie kapitatem..., s. 84; R. Donckles, A. Mittinen, New Findings and Perspectives in Entrepreneurship, Gower Pub, Arebary 1990, s. 38, za: T. Piecuch, Przedsiębiorczość. Podstawy teoretyczne, C.H. Beck, Warszawa 2013, s. 41.

14 P.F. Drucker, Innowacja i przedsiębiorczość. Praktyka i zasady, PWE, Warszawa 1992, s. 34,39 . 
są inne kompetencje osobiste, jak np. inicjatywa, samoorganizacja czy współpraca w zespole. Kreatywność należy do tzw. kompetencji miękkich i można wyróżnić jej cztery wymiary: poznawczy (np. elastyczność intelektualna), funkcjonalny (zdolność generowania dużej liczby pomysłów), behawioralny (np. podejmowanie inicjatywy), metakompetencji (np. autokreacja). W naukach o zarządzaniu kreatywność jest też ujmowana jako wymiar osobowości i wtedy zalicza się ją do kompetencji innowacyjnej ${ }^{15}$.

Kreatywność stanowi warunek inicjujący innowacyjność, jest jej podstawą, ale o ile kreatywność determinuje pojawienie się nowych pomysłów i nie zakłada realizacji idei i w tym znaczeniu jest istotnym elementem powstawania innowacyjnego pomysłu, to innowacyjne zachowanie zakłada wdrożenie i stosowanie nowych czy ulepszonych sposobów działania. Innymi słowy, kreatywność związana jest generowaniem pomysłu, a innowacyjność to zdolność jego zastosowania i źródło znaczących korzyści.

Uznanie kreatywności za podstawowy składnik kapitału ludzkiego wymaga tworzenia środowiska sprzyjającego jej budowaniu. W literaturze przedmiotu uwarunkowania kreatywności w organizacji przedstawia się w postaci formuły $4 \mathrm{P}^{16}$ :

- people (ludzie) - pracownicy (jednostka, grupa),

- process (proces) - proces kreatywności obejmujący: identyfikację problemu, gromadzenie informacji, zastanowienie się nad alternatywnymi rozwiązaniami, zastosowanie technik kreatywnych i ocenę wszystkich rozwiązań,

- press (presja) - rozumiana jako środowisko i uwarunkowania procesu kreacji,

- product (produkt, usługa) - rezultat kreatywności.

Uznanie kreatywności za podstawowy składnik kapitału ludzkiego wymaga tworzenia środowiska sprzyjającego jej budowaniu. Ważnym czynnikiem budowania środowiska ku kreatywności jest kultura organizacyjna rozumiana jako zespół powszechnie akceptowanych norm i wartości, sposobów myślenia, postaw i zachowań pracowników. Tworzeniu prokreatywnej kultury sprzyja odformalizowanie struktur, uelastycznienie procedur, a przede wszystkim stosowanie systemów moty-

15 A. Wojtczak-Turek, Rozwijanie kompetencji twórczych, SGH, Warszawa 2010, za: Zarządzanie kapitałem..., s. 86.

16 E. Nęcka, Psychologia twórczości, Gdańskie Wydawnictwo Psychologiczne, Gdańsk 2001, s. 19-23; Innowacyjność organizacji..., s. 47. 
wacyjnych promujących pomysłowość, doskonalenie i rozwój kompetencji, a także styl kierowania. Kierowanie powinno być inspirującym oddziaływaniem na pracowników w celu wywołania ich zaangażowania i nieskrępowanego dzielenia się pomysłami (styl partnerski). Współcześni menedżerowie są, a przynajmniej winni być przekonani, że w organizacji trzeba dzielić się wiedzą i budować ją na wzajemnym porozumieniu i współpracy, bo to prowadzi do pełnego zaangażowania, kiedy pracownicy „całym sercem i duszą utożsamiają się z realizacją celów organizacji” ${ }^{17}$.

\section{Pracownicy o wysokim potencjale}

Szczególnym źródłem kreatywności są pracownicy o wysokim potencjale określani jako talenty, czyli kluczowi pracownicy. Ich cechą jest wyjątkowość, ale zarazem ograniczona podaż, aby zaspokoić wynikający ze współczesnych trendów popyt na pracowników wyjątkowych, charakteryzujących się potencjałem twórczym (oryginalne i elastyczne zdolności myślenia, kreatywne rozwiązywanie problemów, otwartość, zdolność do podejmowania ryzyka, inteligencja emocjonalna) i zaangażowaniem w działanie wynikające $\mathrm{z}$ wewnętrznej dyscypliny, wytrwałości w dążeniu do realizacji długofalowych celów, pracowitości, głębokiego przekonania o wartości wykonywanej pracy. Tacy pracownicy reprezentują wysoką wartość dodaną, stanowią rdzeń kapitału ludzkiego przedsiębiorstwa, a nawet swego rodzaju inwestycję przedsiębiorstwa. Dlatego pozyskanie, rozwijanie i utrzymanie pracowników o wysokim potencjale jest kluczowym zadaniem współczesnych przedsiębiorstw. Potrzeba spójnego i kompleksowego podejścia do tego zagadnienia zaowocowała powstaniem koncepcji zarządzania talentami wspieranej strategią praca - życie - rodzina i o ile na początku traktowana była jako jeden z obszarów funkcjonalnych czy też narzędzi zarządzania kapitałem ludzkim, to dzisiaj jest filozofią zarządzania kapitałem ludzkim przenikającą jego wszystkie procesy ${ }^{18}$. Niech o wadze kluczo-

17 M. Białasiewicz, Współdziałanie - pożądana kompetencja, w: Wybory strategiczne $w$ przedsiębiorstwach. Strategie funkcjonalne, red. E. Urbanowska-Sojkin, Wydawnictwo Naukowe Uniwersytetu Ekonomicznego w Poznaniu, Poznań 2011, s. 11-20; eadem, Kompetencje menedżerów w przedsiębiorstwie zorientowanym na wiedzę, w: Zarządzanie wartościa przedsiębiorstwa $w$ warunkach kry$z y s u$, red. E. Urbańczyk, Zeszyty Naukowe Uniwersytetu Szczecińskiego, „Finanse, Rynki Finansowe, Ubezpieczenia" 2010, nr 35, s. 25-38.

18 M. Armstrong, A. Baran, Zarządzanie kapitałem ludzkim. Uzyskiwanie wartości dodanej dzięki ludziom, Oficyna a Wolters Kluwer business, Kraków 2008, s. 124; E. Stroińska, Elastyczne formy zatrudnienia. Telepraca - zarządzanie praca zdalna, Poltext, Warszawa 2012, s. 64. 
wych pracowników świadczy ta opinia: „Nie udawaj, że nie jesteś uzależniony od kluczowych pracowników. Nieraz widziałem menedżerów, którzy bagatelizowali znaczenie swoich najlepszych podwładnych - czy im naprawdę się wydaje, że ci fachowcy są tacy głupi? Oczywiście nie ma ludzi niezastąpionych i w ostateczności zespół poradzi sobie bez nich, nigdy jednak nie próbuj umniejszać wartości kluczowych pracowników"19.

Wyjątkowość pracowników o wysokim potencjale wymaga odpowiedniego zarządzania w długiej perspektywie zgodnie z założeniami przyjętej strategii biznesowej i powinno mieć charakter holistyczny. Proces zarządzania talentami obejmuje więc planowanie zatrudnienia, dobór, utrzymanie pracowników, rozwój potencjału, ocenę efektów pracy, planowanie kariery i powinien przynieść korzyści zarówno przedsiębiorstwu, jak i pracownikowi ${ }^{20}$.

Trudno o jednoznaczną definicję talentu, ale wydaje się, że winien się on charakteryzować wymienionymi wyżej potencjalnymi zdolnościami. Z punktu widzenia miejsca talentu w strategii rozwoju przedsiębiorstwa znaczenie ma podział na talenty: unikalne, nadzwyczajne, normalnego życia i zbyteczne ${ }^{21}$. Realizacja strategicznych przedsięwzięć biznesowych wymaga, jak zauważono wcześniej, twórczości i kreatywności, co tym samym orientuje przedsiębiorstwa na pozyskiwanie ludzi mających określone predyspozycje zawodowe. Pozyskiwanie utalentowanych pracowników zależy oczywiście od potrzeb, ale zdolność w tym zakresie można świadomie kreować z wykorzystaniem instrumentów tzw. employer branding ${ }^{22}$. Należy jednak zauważyć, że choć proces pozyskiwania talentów jest najważniejszą częścią strategii zarządzania talentami, to jednak koncentracja wyłącznie na nim byłaby mało efektywna. Talentami trzeba efektywnie zarządzać, dopóki są potrzebni organizacji, odpowiednio ich motywując i budując zaangażowanie organizacyjne.

19 N. Peeling, Błyskotliwy menedżer. Co dobry menedżer wie, robi i mówi, PWE, Warszawa 2010, s. 31.

20 D. Ruse, K.E. Jansen, Stay in Front of the Talent Curie. Strategic Workforce Planning Can Help Companies Forecast Their Future Leeds for Scientists and Engineers, „Research - Technology Management" 2008, No. 51, s. 38, za: J. Grodzicki, Talent w przedsiębiorstwie opartym na wiedzy, Wydawnictwo Uniwersytetu Gdańskiego, Gdańsk 2011, s. 179.

21 J. Grodzicki, op.cit., s. 155.

22 Szerzej zagadnienie polityki rekrutacyjnej zorientowanej na bardziej utalentowanych pracowników m.in. w: E. Michales, H. Handfield-Jones, B. Axelrod, The War for Talent, Harvard Business School Press, Boston 2001, s. 70. 
Przy czym, jak zauważa T. Listwan ${ }^{23}$, w procesach motywowania i rozwoju talentów ważne jest samodoskonalenie, a programy rozwojowe są coraz bardziej ukierunkowane na kluczowe role organizacyjne, np. odrębne programy dla młodych talentów (absolwentów), dla menedżerów przygotowujące do objęcia wyższych stanowisk w organizacji czy dla specjalistów/ekspertów.

\section{Przykłady dobrych praktyk}

W ramach stymulowania kreatywności ma miejsce wprowadzenie tzw. dobrych praktyk w postaci kompleksowych projektów czy też programów zorientowanych na wybrane aspekty działalności organizacji, których celem jest osiągnięcie zamierzonych celów. Poniżej zaprezentowano wybrane przykłady odnoszące się do dobrych praktyk w gospodarce, które mogą być wzorem do naśladowania bądź źródłem inspiracji do zaprojektowania przez organizację własnych programów czy projektów.

Firma Google, globalny gigant internetowy, pozwala swoim pracownikom przeznaczać $10 \%$ ich czasu pracy na realizację własnych pomysłów niezwiązanych z głównymi zadaniami, dzięki czemu powstaje wiele ważnych rozwiązań24 ${ }^{2}$ a np. w firmie Xerox czy PWC Consulting pozwala się pracownikom na spędzanie czasu pracy na uczeniu się.

Firma British American Tobacco stworzyła katalog kluczowych zasad dla wszystkich pracowników: siła wynikająca z różnorodności, otwartość i partnerstwo, delegowanie i odpowiedzialność, duch przedsiębiorczości. Panuje idea równości, w ramach której m.in. premiuje się osoby osiągające najlepsze efekty, utalentowane i zmotywowane do pracy.

W firmie Philips Polska w ramach oceny pracowniczej ocenia się aktywność osoby na polu dzielenia się wiedzą, uzyskiwania wiedzy z zewnątrz czy inicjowania działań pomiędzy różnymi organizacjami w ramach firmy w myśl sloganu: „Zdobywaj z dumą, dziel się z przyjemnością". Jednostką koordynującą jest Korporacyjne Biuro Jakości.

Również polskie firmy stosują systemy zarządzania kapitałem ludzkim zorientowane na talenty mające zapewnić potencjał kreatywności. I tak np.:

23 T. Listwan, Zarzadzanie talentami - wyzwanie współczesnych organizacji, w: Zarządzanie talentami, red. S. Borkowska, IPiSS, Warszawa 2005, s. 22-25.

24 www.rp.pl/artykul/835908.html?point=takgp=0 (4.02.2015). 
1. W Banku Millenium SA pracownicy o wysokim potencjale objęci są Programami Rozwojowymi zakładającymi szkolenia w zakresie rozwoju kluczowych kompetencji. Nad rozwojem zawodowym tych pracowników czuwa mentor w osobie członka zarządu, a dwa razy w roku organizowane jest dla nich Forum Rozwojowe.

2. Firma LOTOS SA realizuje specjalne programy ukierunkowane na pracowników o wysokim potencjale, np. Program Indywidualnych Ścieżek Rozwoju, Program Kadry Rezerwowej, Program Absolwent, Akademia LOTOS.

3. Polska Telefonia Cyfrowa Sp. z o.o. dla pracowników, których kompetencje i zaangażowanie $\mathrm{w}$ powierzone im projekty zostały ocenione jako ponadprzeciętne, przygotowała program XL Talent obejmujący szkolenia, studia finansowane przez firmę, staże, indywidualne ścieżki rozwoju.

4. W spółkach Grupy Telekomunikacji Polskiej realizuje się szereg inicjatyw nastawionych na budowanie klimatu innowacyjnego, poszukiwanie źródeł innowacji, pozyskiwanie nowych idei, zarządzanie pomysłami. Istotnym elementem funkcjonującym w Katowicach jest projekt pod nazwą Gabinet Projektowy, którego celem jest tworzenie przestrzeni kreatywnej m.in. przez kształtowanie sprzyjającego środowiska pracy ${ }^{25}$.

\section{Podsumowanie}

Współczesne organizacje funkcjonują w warunkach wielu nowych zjawisk, które prowadzą do zmiany paradygmatów. W sferze ludzkiej przejawia się to zastąpieniem koncepcji zasobowej koncepcją zarządzania kapitałem ludzkim przyjmującą m.in. traktowanie pracowników jako szczególnego kapitału, którego istotnym składnikiem jest kreatywność tak w wymiarze indywidualnym, jak i zbiorowym.

Wejście organizacji na ścieżkę budowania organizacji kreatywnej oznacza budowanie kultury kreatywności, a ta zaczyna się od jednostki, co tym samym oznacza, że podstawą rozwijania kreatywności w organizacji powinny być działania z zakresu zarządzania kapitałem ludzkim. Do działań tych zaliczyć należy m.in. budowanie systemu kompetencyjnego i pozyskiwanie osób o wysokim potencjale twórczym

25 Przykłady dobry praktyk opracowano na podstawie: R. Drozdowski, A. Zakrzewska, K. Puchalska, M. Morchat, D. Mroczkowska, Wspieranie postaw proinnowacyjnych przez wzmacnianie kreatywności jednostki, PARP, Warszawa 2010, s. 86-101. 
czy budowanie postaw wobec pracy zorientowanych na kreowanie zmian, umiejętność pracy w zespole, zaangażowanie.

Pozyskiwanie, utrzymanie i rozwój pracowników o wysokim potencjale staje się dla wielu organizacji priorytetem i wymaga opracowania strategii zarządzania pracownikami utalentowanymi, która musi być spójna ze strategią organizacji.

\section{Literatura}

Antczak Z., Kapitat intelektualny $i$ kapitat ludzki w ewoluującej przestrzeni organizacyjnej, Wydawnictwo Uniwersytetu Ekonomicznego we Wrocławiu, Wrocław 2013.

Armstrong M., Baran A., Zarzązanie kapitatem ludzkim. Uzyskiwanie wartości dodanej dzięki ludziom, Oficyna a Wolters Kluwer business, Kraków 2008.

Białasiewicz M., Kompetencje menedżerów w przedsiębiorstwie zorientowanym na wiedzę, w: Zarzadzanie wartościa przedsiębiorstwa w warunkach kryzysu, red. E. Urbańczyk, Zeszyty Naukowe Uniwersytetu Szczecińskiego, „Finanse, Rynki Finansowe, Ubezpieczenia" 2010, nr 35 .

Białasiewicz M., Wspótdziałanie - pożądana kompetencja, w: Wybory strategiczne w przedsiębiorstwach. Strategie funkcjonalne, red. E. Urbanowska-Sojkin, Wydawnictwo Naukowe Uniwersytetu Ekonomicznego w Poznaniu, Poznań 2011.

Brzeziński M., Organizacja kreatywna, Wydawnictwo Naukowe PWN, Warszawa 2009.

Domański S.R., Kapitał ludzki i wzrost gospodarczy, Spis, Warszawa 1993.

Drozdowski R., Zakrzewska A., Puchalska K., Morchat M., Mroczkowska D., Wspieranie postaw proinnowacyjnych przez wzmacnianie kreatywności jednostki, PARP, Warszawa 2010.

Drucker P.F., Innowacja i przedsiębiorczość. Praktyka i zasady, PWE, Warszawa 1992.

Elastyczne zarzadzanie kapitałem ludzkim w organizacji wiedzy, red. M. Juchnowicz, Difin, Warszawa 2007.

Grodzicki J., Talent $w$ przedsiębiorstwie opartym na wiedzy, Wydawnictwo Uniwersytetu Gdańskiego, Gdańsk 2011.

http://psychologia-twórczości-wykłady.org/wykład/72_psychologia-twórczości-pojęcietwórczości.html (4.02.3015).

http://www.kluczdokariery.pl/twoja-kariera/rozwój-osobisty/kreatywność/art.,2kreatywnoscw-pracy-,html (3.02.2015).

http://www.rp.pl/artykul/835908.html?point=takgp=0 (4.02.2015).

Innowacyjność organizacji $w$ strategii inteligentnego i zrównoważonego rozwoju, red. J. Wiśniewska, K. Janasz, Difin, Warszawa 2012. 
Janowska Z., Zarzadzanie zasobami ludzkimi, PWE, Warszawa 2010.

Jerzyk E., Kreatywność - uwarunkowania i ocena, w: Kreatywność w biznesie, red. E. Jerzyk, G. Leszczyński, H. Mruk, Wydawnictwo Akademii Ekonomicznej w Poznaniu, Poznań 2006.

Kształtowanie kapitału ludzkiego w organizacji, red. M. Białasiewicz, Wydawnictwo Naukowe Uniwersytetu Szczecińskiego, Szczecin 2013.

Listwan T., Zarzadzanie talentami - wyzwanie współczesnych organizacji, w: Zarządzanie talentami, red. S. Borkowska, IPiSS, Warszawa 2005.

Michales E., Handfield-Jones H., Axelrod B., The War for Talent, Harvard Business School Press, Boston 2001.

Nęcka E., Psychologia twórczości, Gdańskie Wydawnictwo Psychologiczne, Gdańsk 2001.

Nęcka E., Wymiary twórczości, w: Nowe teorie twórczości. Nowe metody pomocy w tworzeniu, Oficyna Wydawnicza Impuls, Kraków 2002.

Peeling N., Blyskotliwy menedżer. Co dobry menedżer wie, robi i mówi, PWE, Warszawa 2010.

Piecuch T., Przedsiębiorczość. Podstawy teoretyczne, C.H. Beck, Warszawa 2013.

Pocztowski A., Kapitat intelektualny a zarzadzanie zasobami ludzkimi, Zeszyty Naukowe Akademii Ekonomicznej w Krakowie 2005, nr 629.

Podstawy zarzadzania przedsiębiorstwami w gospodarce opartej na wiedzy, red. B. Mikuła, A. Pietruszka-Ortyl, A. Potocki, Difin, Warszawa 2007.

Sajkiewicz A., Człowiek - kreator wartości przedsiębiorstwa, w: Zarządzanie wartościa firmy, red. A. Szablewski, Poltext, Warszawa 1999.

Schulz T.W., Investing in People: The Economics of Popultion Quality, University of California, Berkley 1981.

Słownik wyrazów obcych, Wydawnictwo Naukowe PWN, Warszawa 2004.

Stroińska E., Elastyczne formy zatrudnienia. Telepraca - zarzadzanie praca zdalna, Poltext, Warszawa 2012.

Strużyna J., Kapitał ludzki i przedsiębiorczość - aspekty teoretyczne, w: Kapitał ludzki a kształtowanie przedsiębiorczości, red. M. Juchnowicz, Poltext, Warszawa 2004.

Strużyna J., Wymiary kapitału ludzkiego, w: Kształtowanie kapitału ludzkiego firmy, red.

B. Kożuch, Wydawnictwo Uniwersytetu w Białymstoku, Białystok 2000.

Wojtczak-Turek A., Rozwijanie kompetencji twórczych, SGH, Warszawa 2010.

Zarządzanie kapitałem ludzkim. Procesy - narzędzia - aplikacje, red. M. Juchnowicz, PWE,

Warszawa 2014.

Zarządzanie zasobami ludzkimi. Tworzenie kapitatu ludzkiego w organizacji, red. H. Król, A. Ludwiczyński, Wydawnictwo Naukowe PWN, Warszawa 2006. 


\title{
CREATIVITY AND TALENT IN THE CONCEPT OF HUMAN CAPITAL
}

\begin{abstract}
This article presents the concept of human capital in conditions of organisations which evolve in the creative organisation. This trend elicits changes in many areas of organisations. It requires adequate changes in human management. They reflect activities which cause the development of individual creativity as well as corporate creativity. Moreover these changes help to hold and develop employees that have high potential and talent. Employees with extraordinary skills have creative potential. They can solve the problem. This paper discusses the human capital - creativity as competence - talents and shows good examples from this area.
\end{abstract}

Translated by Wojciech Leoński

Keywords: human capital, creativity, talents

JEL Codes: J24, O15 
